\title{
Origin and fate of methane in the Eastern Tropical North Pacific oxygen minimum zone
}

\author{
Panagiota-Myrsini Chronopoulou ${ }^{1,2}$, Felicity Shelley ${ }^{1}$, William J Pritchard ${ }^{3}$, \\ Susanna T Maanoja ${ }^{4}$ and Mark Trimmer \\ School of Biological and Chemical Sciences, Queen Mary University of London, London, UK
}

\begin{abstract}
Oxygen minimum zones (OMZs) contain the largest pools of oceanic methane but its origin and fate are poorly understood. High-resolution $(<15 \mathrm{~m})$ water column profiles revealed a $300 \mathrm{~m}$ thick layer of elevated methane (20-105 nM) in the anoxic core of the largest OMZ, the Eastern Tropical North Pacific. Sediment core incubations identified a clear benthic methane source where the OMZ meets the continental shelf, between 350 and $650 \mathrm{~m}$, with the flux reflecting the concentration of methane in the overlying anoxic water. Further incubations characterised a methanogenic potential in the presence of both porewater sulphate and nitrate of up to $88 \mathrm{nmol} \mathrm{g}^{-1}$ day $^{-1}$ in the sediment surface layer. In these methane-producing sediments, the majority $(85 \%)$ of methyl coenzyme M reductase alpha subunit (mcrA) gene sequences clustered with Methanosarcinaceae $(\geqslant 96 \%$ similarity to Methanococcoides sp.), a family capable of performing non-competitive methanogenesis. Incubations with ${ }^{13} \mathrm{C}_{-} \mathrm{CH}_{4}$ showed potential for both aerobic and anaerobic methane oxidation in the waters within and above the OMZ. Both aerobic and anaerobic methane oxidation is corroborated by the presence of particulate methane monooxygenase $(p m o A)$ gene sequences, related to type I methanotrophs and the lineage of Candidatus Methylomirabilis oxyfera, known to perform nitritedependent anaerobic methane oxidation (N-DAMO), respectively.

The ISME Journal (2017) 11, 1386-1399; doi:10.1038/ismej.2017.6; published online 28 February 2017
\end{abstract}

\section{Introduction}

Methane is the most abundant hydrocarbon in the atmosphere and a potent greenhouse gas, which has contributed $\sim 20 \%$ to the Earth's warming since preindustrial times (Lashof and Ahuja, 1990; Reeburgh, 2007; Kirschke et al., 2013). The marine environment encompasses large reservoirs of methane (Zhang et al., 2011; Pack et al., 2015), particularly in oxygen minimum zones (OMZs). Here, oxygen is consumed faster than it is resupplied, resulting in a layer of hypoxic waters surrounding a functionally anoxic core (Thamdrup et al., 2012), where methane accumulates (Wright et al., 2012). Under a warming climate, the dissolution of oxygen in seawater will

Correspondence: M Trimmer, School of Biological and Chemical Sciences, Queen Mary University of London, Mile End Road, London, E1 4NS, UK.

E-mail: m.trimmer@qmul.ac.uk

${ }^{1}$ These authors contributed equally to this work.

${ }^{2}$ Current address: Department of Environmental Sciences, University of Helsinki, PO Box (Viikinkaari 1), 00014, Helsinki, Finland.

${ }^{3}$ Current address: Faculty of Life Sciences, University of Manchester, A4051 Michael Smith Building, Dover Street, Manchester, M13 9PT, UK.

${ }^{4}$ Current address: Department of Chemistry and Bioengineering, Tampere University of Technology, PO Box 541, FI-33101, Tampere, Finland.

Received 22 June 2016; revised 6 December 2016; accepted 9 January 2017; published online 28 February 2017 decrease, whereas its consumption through respiration will likely increase (Vázquez-Domínguez et al., 2007) and thermal stratification could become more intense. Together, these biotic and abiotic changes will thicken OMZs moving these large methane pools closer to the zone of atmospheric exchange (Stramma et al., 2008; Keeling et al., 2010; Helm et al., 2011).

Marine methanogenesis, which produces $0.7-1.4 \mathrm{Tg}$ each year (Krüger et al., 2005), forms an essential link in the carbon cycle, preventing the long-term burial of carbon in the sediments by mineralising it and returning it to the water in gaseous form (Ferry and Lessner, 2008). The thermodynamics of organic matter oxidation dictate that sulphate reduction and methanogenesis should be mutually exclusive reactions. Although the clear spatial partitioning of these two microbial processes has been widely observed in marine sediments (Martens and Berner, 1977; Whiticar, 2002; Reeburgh, 2007), non-competitive methanogenesis can co-occur with other anaerobic processes (Valentine, 2011). Non-competitive methanogenisis disproportionates methylated substrates (for example, methyl amine, methane thiols and methanol) to yield methane and carbon dioxide, and since its discovery in the early 1980s (Oremland et al., 1982), it has been found to occur in all major oceans (D'Hondt et al., 2002; Mitterer, 2010; Valentine, 2011). However, relatively little scientific 
attention has focused on microbial methanogenesis compared with that around gas hydrates and cold seeps (Shakhova et al., 2005; Valentine, 2011; Boetius and Wenzhofer, 2013).

The majority of methane produced in marine sediments is thought to be oxidised anaerobically, limiting its flux to the overlying water (Knittel and Boetius, 2009). Any methane leaking into the water column may still be oxidised, by pelagic aerobic or anaerobic bacteria, which form a final barrier preventing its escape to the atmosphere (Reeburgh et al., 1991; Blumenberg et al., 2007; Kessler et al., 2011; Heintz et al., 2012).

We focused on locating the origin of methane in the Eastern Tropical North Pacific (ETNP), between 70 and $720 \mathrm{~km}$ off the Guatemalan coast. The ETNP OMZ is both the world's largest OMZ (Paulmier and Ruiz-Pino, 2009) and the largest reservoir of oceanic methane (Sansone et al., 2001, 2004; Reeburgh, 2007; Naqvi et al., 2010). Here, the methane is thought to be formed by a combination of decomposing sinking organic matter and coastal or benthic sources but neither have been directly measured (Sansone et al., 2001, 2004). Porewater and bottom-water methane concentrations along with stable isotope ratio data suggested the sediments were the source of the pelagic methane and the flux was greatest where the anoxic core of the OMZ touched the sediment (western Mexican margin, Sansone et al. (2004)). Although these studies offer useful insights, there are no direct measurements of sediment methanogenesis or methane efflux in a marine OMZ.

Pelagic methane oxidation in marine environments is a rarely quantified process but on the margins of an OMZ, where methane intersects traces of oxygen, it could be a significant process. Published rates span $\sim 0.001-10 \mathrm{nmol}^{-1}$ day $^{-1}$ and all studies used either ${ }^{3} \mathrm{H}-\mathrm{CH}_{4}$ or LL- ${ }^{14} \mathrm{C}$ as a tracer (Mau et al., 2013). The only study to have successfully measured methane oxidation in the ETNP OMZ (Pack et al., 2015) found exceptionally slow rates (0.000034-4 nmol ${ }^{-1}$ day $\left.^{-1}\right)$, which could explain how the methane, if of benthic origin, can be sustained hundreds of kilometres offshore.

We used high-resolution water column profiles to show that methane concentrations peak in the anoxic core of the ETNP OMZ. We then used a combination of water and sediment incubations, along with stable isotope tracers and molecular analyses, to quantify sediment methane flux, methanogenic potential and pelagic methane oxidation potentials. We hypothesised that all sediments would contain active methanogens, but that their activity would be controlled by the oxygen concentration in the bottom-water. Further, the methane released from the sediments is then oxidised by aerobic and/or anaerobic methanotrophs in the water column as it moves towards the OMZ margins. To the best of our knowledge, this is the first study to combine biogeochemical with molecular microbial data, in order to better understand the origins and fate of methane in the ocean's largest OMZ.

\section{Materials and methods}

\section{Sample sites}

This study comprised two cruises in the ETNP: the first (D373, 11 December 2011-13 January 2012), which focused on the water column (0-4000 m), was structured around 6 'offshore' sites located along $92.5^{\circ} \mathrm{W}$, between 8 and $13^{\circ} \mathrm{N}$ (Supplementary Figure S1). The second (JC097, 28 December 201310 February 2014), concentrated on the continental shelf and slope, 70-150 km off the Guatemalan coast (Supplementary Figure S1) and here, both sediments and water column samples were collected. A standard conductivity-temperature-depth rosette, comprising 24 Niskin (20 litre) bottles and a Sea-Bird 24 electronics system (fluorimeter, altimeter, photosynthetically active radiation and oxygen sensors, and so on) was used to collect water and a multicorer (Mega Corer, OSIL, Havant, UK) was used to recover intact cores of sediment and overlying water.

\section{Water column gas and nutrient profiles}

High-resolution (5-15 m) water column profiles $(n=21)$ were constructed to define the OMZ and locate the methane. To minimise atmospheric contamination, water for methane analysis was discharged from the Niskin bottles into $12.5 \mathrm{ml}$ gas-tight vials (Labco, Lampeter, UK) via Tygon tubing and allowed to overflow three times before capping, temperature equilibration and head-spacing $(2 \mathrm{ml}$ helium (BOC, Guildford, UK)). Methane was measured on-board using a gas chromatograph fitted with a flame ionisation detector (gas chromatography/flame ionization detector Agilent Technologies (Santa Clara, CA, USA), see Sanders et al. (2007) for details). Oxygen concentrations were measured by the Sea-Bird sensor (Bellevue, WA, USA) (with a limit of detection (LOD) $\sim 1.4 \mathrm{~mol} \mathrm{l}^{-1}$ ) and nitrite was measured using a segmented flow auto-analyser (Skalar, Breda, Netherlands; LOD $=0.05 \mathrm{mmol}^{-1}$, Nicholls et al., 2007).

\section{Sediments as a methane source}

Sediment-water flux was determined using intact cores and the methanogenic potential of discrete layers was quantified using slurries. As the conductivity-temperature-depth could not sample closer than $\sim 10 \mathrm{~m}$ from the seabed, the water overlying the sediment ( $n=3$ from the least disturbed core) was sampled, as above, to measure the methane concentration as close to the seabed as possible $(<15 \mathrm{~cm})$. Next, six sediment mini-cores were subsampled from three of the large cores (using Perspex tubes, $3.4 \times 25 \mathrm{~cm}$ ), sealed with rubber bungs and transferred to a temperature controlled $\left(10^{\circ} \mathrm{C}\right)$ tank. This 
was repeated at 16 locations ranging in seabed depth from 100 to $900 \mathrm{~m}$.

Methane flux was quantified by measuring methane in the overlying water before and after a sealed 24-h incubation. First, the overlying water was degassed by bubbling ( $2 \mathrm{~min}$ ) with oxygen-free nitrogen (BOC), to ensure all cores were incubated under the same hypoxic conditions (precise concentration verified using an oxygen micro-sensor, Unisense, Aarhus, Denmark) and that the majority of ambient methane was removed (previous experiment had demonstrated that 2 min was sufficient to remove $>90 \%$ methane). Water samples were taken from each mini-core after degassing $\left(\mathrm{T}_{0}\right)$, they were then sealed with bungs with inbuilt magnetic stirrers, and left for $24 \mathrm{~h}$ in the dark until a second water sample $\left(\mathrm{T}_{\text {final }}\right)$ was taken for methane analysis. The daily flux of methane was calculated as the increase between $\mathrm{T}_{0}$ and $\mathrm{T}_{\text {final }}$.

To identify the sediment layer with the greatest methanogenic potential, additional large sediment cores (six locations, Table 1) were carefully extruded and $\sim 4 \mathrm{ml}$ of sediment and $3 \mathrm{ml}$ of bottom water (overlying the cores) was transferred to gas-tight vials using a truncated $1 \mathrm{ml}$ syringe (to minimise air contamination) to create a slurry. The headspace and water was purged with helium for $2 \mathrm{~min}$ to deoxygenate the vials and optimise conditions for methanogenesis. The methane concentration in the headspace was measured by gas chromatography/ flame ionization detector 4-8 times over the following 4-12 days and between measurements vials were kept at $12{ }^{\circ} \mathrm{C}$ in the dark. Following the first two experiments $(550 \mathrm{~m}$ and $650 \mathrm{~m}$ ), only the top $5 \mathrm{~cm}$ was used for further sites.

The concentration of sulphate, nitrite and nitrate in the sediment porewater was measured in eight large cores from four different locations $(150,350$, 550 and $750 \mathrm{~m}$ seabed depth) by ion chromatography (Dionex, Sunnyvale, CA, USA; for sulphate) and segmented flow auto-analyser (Skalar for nitrite and nitrate), after separating the porewater from the sediment by centrifugation. Finally, hydrogen sulphide was measured in the cores by inserting a calibrated, miniaturised amperometric sensor (Unisense) into an extruded portion of the core, from the side, at $2 \mathrm{~cm}$ intervals.

\section{Aerobic and anaerobic water column methane oxidation}

We set up four experiments using ${ }^{13} \mathrm{C}$-labelled methane to quantify the potential for aerobic and anaerobic methane oxidation in the water column (Supplementary Figure S2). First, we set up short time experiments with water from the upper margin of the OMZ, where oxygen is at the LOD (200 and $226 \mathrm{~m})$. Seawater saturated with $99.9 \%{ }^{13} \mathrm{C}^{-} \mathrm{CH}_{4}$ was used to spike the samples with $3.3 \mathrm{nmol}{ }^{13} \mathrm{C}_{-}-\mathrm{CH}_{4}$ ( $264 \mathrm{nmol} \mathrm{L}^{-1}$ ) to avoid the need for a headspace and, thus, maintain ambient oxygen conditions. Samples
Table 1 Methanogenic slurry potentials in which the methane concentration was measured daily

\begin{tabular}{lcccc}
\hline $\begin{array}{l}\text { Seafloor } \\
\text { depth }(\mathrm{m})\end{array}$ & $\begin{array}{c}\text { Mean sedi- } \\
\text { ment } \\
\text { depth }(\mathrm{cm})\end{array}$ & $\begin{array}{c}\text { Methanogenesis } \\
\left(\mathrm{nmol} \mathrm{g}^{-1} \text { day }^{-1}\right)\end{array}$ & s.e. & $\begin{array}{c}\text { Number of } \\
\text { replicates }\end{array}$ \\
& & &
\end{tabular}

\begin{tabular}{ccccc}
\hline \multirow{3}{*}{350} & Water & 0 & 0.003 & 4 \\
& 1 & 0.67 & 0.229 & 6 \\
350 & 3 & 0.44 & 0.402 & 6 \\
& Water & 0 & 0.001 & 2 \\
550 & 1 & 17.87 & 7.82 & 4 \\
& 3 & 2.19 & 1.85 & 4 \\
& Water & 0.01 & 0.002 & 4 \\
& 2.5 & 4.66 & 2.288 & 2 \\
& 7.5 & 0.08 & 0.008 & 2 \\
550 & 12.5 & 0.06 & 0.012 & 2 \\
& 17.5 & 0.06 & 0.022 & 2 \\
& 22.5 & 0.05 & 0.003 & 2 \\
650 & Water & 0.01 & 0.012 & 4 \\
& 1 & 13.09 & 5.213 & 6 \\
& 3 & 0.27 & 0.028 & 6 \\
& Water & 0.004 & 0.0008 & 8 \\
& 2.5 & 9.73 & 1.162 & 4 \\
& 7.5 & 0.03 & 0.007 & 4 \\
750 & 12.5 & 0.03 & 0.008 & 4 \\
& 17.5 & 0.02 & 0.001 & 2 \\
& 22.5 & 0 & - & 1 \\
& Water & 0.002 & 0.0025 & 2 \\
& 1 & 87.84 & 15.32 & 4 \\
& 3 & 0.32 & 0.040 & 4 \\
\hline
\end{tabular}

Mean rates of methane production ( \pm s.e.) are presented for discrete sediment depth intervals and for the water immediately overlying the sediment. The rate of methanogenesis was calculated over 3-5 days depending on the linearity of production with time. Cores were collected from six locations with varying seabed depths. Two separate locations, where the seabed depth was $550 \mathrm{~m}$, were targeted.

were fixed $(100 \mu \mathrm{l}$ of $12.2 \mathrm{M} \mathrm{HCl})$ at $3-5$ time points over 10-15 days to track the accumulation of dissolved inorganic carbon $\left({ }^{13} \mathrm{C}-\mathrm{DIC}\right)$.

Second, we set up dose-response experiments (65 and $200 \mathrm{~m}$ ), whereby we varied the injection volume to give a range of methane concentrations (44$790 \mathrm{nmoll}^{-1}$ ) to assess the extent to which the methanotrophic community was substrate limited. These were left for the duration that the samples took to get back to the UK (5 months), without a headspace, before fixing.

Third, we started more widespread long-term incubations (eight locations) at one methane concentration (264 $\mathrm{nmoll}^{-1}$ ) and after fixing a sample within 2 min (control), we incubated the remaining samples for 5 months at $12{ }^{\circ} \mathrm{C}$ in the dark. Finally, to test for the potential for nitrite-dependent anaerobic methane oxidation (N-DAMO) we incubated water from five depths spanning the upper boundary and into the core of the OMZ, where nitrite and methane were both present (235-412 m, Supplementary Figure S2 and Table 2) with ${ }^{13} \mathrm{C}-\mathrm{CH}_{4}\left(3.4 \mu \mathrm{mol} \mathrm{l}{ }^{-1}\right)$ and ${ }^{15} \mathrm{~N}^{-\mathrm{NO}_{2}}\left(11.4 \mu \mathrm{mol} \mathrm{l}{ }^{-1}\right)$, just ${ }^{13} \mathrm{C}^{-} \mathrm{CH}_{4}$ or no spike. These samples were taken from depths with no detectable oxygen but, to ensure complete anoxia in the water, we introduced a $2 \mathrm{ml}$ helium headspace before adding the gas spikes. For all four types of 
Table 2 Methane oxidation in long-term water incubations at $12{ }^{\circ} \mathrm{C}$

\begin{tabular}{|c|c|c|c|c|c|c|}
\hline $\begin{array}{l}\text { Latitude/ } \\
\text { longitude }\end{array}$ & $\begin{array}{l}\text { Sample water } \\
\text { depth }(\mathrm{m})\end{array}$ & $\begin{array}{l}\text { Ambient oxygen } \\
\left(\mu \mathrm{mol} 1^{-1}\right)\end{array}$ & $\begin{array}{l}\text { Ambient } \\
\text { methane } \\
\left(\text { nmol 1 }^{-1}\right)\end{array}$ & $\begin{array}{l}{ }^{13} \mathrm{C} \text {-DIC pro- } \\
\text { duced (nmol) }\end{array}$ & Initial isotope spikes & $\begin{array}{l}{ }^{15} \mathrm{~N}-\mathrm{N}_{2} \text { pro- } \\
\text { duced (nmol) }\end{array}$ \\
\hline \multirow[t]{4}{*}{$13^{\circ} 21 \mathrm{~N} / 91^{\circ} 23 \mathrm{~W}$} & 195 & 1.9 & 3.1 & $0.2 \pm 0.03$ & $264 \mathrm{nM}^{13} \mathrm{CH}_{4}$ & NA \\
\hline & 200 & 1.5 & 2.8 & $0.6 \pm 0.34$ & & \\
\hline & 205 & $\leqslant 1.4$ & 4.4 & $0.1 \pm 0.09$ & & \\
\hline & 210 & $\leqslant 1.4$ & 3.4 & $0.20 \pm 0.22$ & & \\
\hline \multirow[t]{2}{*}{$13^{\circ} 15 \mathrm{~N} / 91^{\circ} 08 \mathrm{~W}$} & 47 & 132.1 & 4.8 & $-0.1 \pm 0.06$ & & \\
\hline & 226 & $\leqslant 1.4$ & 2.1 & $-0.02 \pm 0.08$ & & \\
\hline \multirow[t]{2}{*}{$13^{\circ} 16 \mathrm{~N} / 91^{\circ} 08 \mathrm{~W}$} & 65 & 11.4 & 2.4 & $0.2 \pm 0.02$ & & \\
\hline & 228 & $\leqslant 1.4$ & 3.9 & $0.3 \pm 0.11$ & & \\
\hline \multirow[t]{2}{*}{$13^{\circ} 25 \mathrm{~N} / 91^{\circ} 23 \mathrm{~W}$} & 235 & $\leqslant 1.4$ & 4.3 & $2.6 \pm 1.25^{\mathrm{a}}$ & & \\
\hline & $235^{*}$ & & & $2.4 \pm 1.11^{\mathrm{a}}$ & & $80.5 \pm 30.11$ \\
\hline \multirow[t]{4}{*}{$13^{\circ} 16 \mathrm{~N} / 91^{\circ} 08 \mathrm{~W}$} & 322 & $\leqslant 1.4$ & 14.8 & $10.4 \pm 0.18^{\mathrm{a}}$ & $\begin{array}{c}3.4 \mu \mathrm{M}{ }^{13} \mathrm{CH}_{4} \text { and for }{ }^{*} \text { samples } \\
\text { also } 11.4 \mu \mathrm{M}{ }^{15} \mathrm{NO}_{2}^{-}\end{array}$ & \\
\hline & $322^{*}$ & & & $11.8 \pm 3.50^{\mathrm{a}}$ & & $16.0 \pm 2.64$ \\
\hline & 412 & $\leqslant 1.4$ & 33.9 & $12.3 \pm 4.03^{\mathrm{a}}$ & & \\
\hline & $412^{*}$ & & & $15.4 \pm 0.78^{\mathrm{a}}$ & & $14.5 \pm 4.11$ \\
\hline \multirow[t]{4}{*}{$13^{\circ} 16 \mathrm{~N} / 91^{\circ} 08 \mathrm{~W}$} & 264 & $\leqslant 1.4$ & 9.4 & $1.3 \pm 1.20^{\mathrm{a}}$ & & \\
\hline & $264^{*}$ & & & $12.0 \pm 6.00^{\mathrm{a}}$ & & $29.3 \pm 18.22$ \\
\hline & 256 & $\leqslant 1.4$ & 6.1 & $11.2 \pm 0.00^{\mathrm{a}}$ & & \\
\hline & $256^{*}$ & & & $0.9 \pm 1.37^{\mathrm{a}}$ & & $8.9 \pm 0.61$ \\
\hline
\end{tabular}

Abbreviations: NA, not applicable; OFN, oxygen-free nitrogen.

Mean values ( \pm s.e., $n=3$ ). Samples marked with 'a' had a $2 \mathrm{ml}$ OFN headspace throughout the incubation. Samples marked with * are those where

${ }^{15} \mathrm{~N}-\mathrm{NO}_{2}\left(11.4 \mu \mathrm{mol} \mathrm{l} \mathrm{l}^{-1}\right)$ was introduced and the production of ${ }^{15} \mathrm{~N}-\mathrm{N}_{2}$ measured after 5 months. Where oxygen was at or below the limit of detection it was assumed to be $\leqslant 1.4 \mu \mathrm{mol} \mathrm{l} \mathrm{l}^{-1}$.

incubations, we included a reference sample (no spike, fixed at same time as samples), a spikedcontrol (spiked with ${ }^{13} \mathrm{C}-\mathrm{CH}_{4}$ and/or ${ }^{15} \mathrm{NO}_{2}$ and killed at the beginning of the experiment) and three technical replicates of each treatment. Microbial activity was stopped, and any resulting ${ }^{13} \mathrm{C}$-DIC converted to ${ }^{13} \mathrm{C}-\mathrm{CO}_{2}$ for analysis, by injecting $\mathrm{HCl}$ through the septa (as above). See Supplementary Figure S2 for sample location details.

Upon return to the UK, all unfixed samples were fixed and a $2 \mathrm{ml}$ helium headspace was introduced into those incubated without one. To confirm the initial $\mathrm{CH}_{4}$ concentration, spiked-control samples were analysed on a gas chromatography/flame ionization detector and then the ${ }^{13} \mathrm{C}$-DIC (and ${ }^{15} \mathrm{~N}$ $\mathrm{N}_{2}$ where necessary) was quantified using an elemental analyser interfaced with a continuous flow isotope ratio mass spectrometer (Sercon 2022, Sercon Group, Crewe, UK), calibrated against sodium bicarbonate ( $0-4 \mathrm{mM}$ for DIC) or air (for $\mathrm{N}_{2}$ ).

\section{Molecular analysis}

Water (see Supplementary Table S1 for details) was filtered either through stand alone pumps or Nalgene filtration units (Supor, Pall, Port Washington, NY, USA; ø $293 \mathrm{~mm}$ for stand alone pumps or $\varnothing$ $47 \mathrm{~mm}$ for Nalgene units, $0.2 \mu \mathrm{m}$ pore size filters). Filters were immediately frozen in liquid nitrogen, placed in $-80^{\circ} \mathrm{C}$ freezer and transferred to the UK for DNA extraction. Sediments (seabed depth 222 , $342,550,650$ and $657 \mathrm{~m}$ ) were collected from the top $2 \mathrm{~cm}$ of the sediment cores into $2 \mathrm{ml}$ cryovials and frozen (as above) until DNA extraction. Details of the extraction process and downstream analysis are given in Supplementary Information.

\section{Accession numbers}

The DNA sequences reported in this study were deposited in the EMBL database under the accession numbers LT575999-LT576028.

\section{Results}

Water column profiles

Over the two cruises, we constructed 21 water column profiles covering seabed depths ranging from 55 to $5320 \mathrm{~m}$. Oxygen declined steeply from an average of $193 \mathrm{\mu moll}^{-1}$ in the top $20 \mathrm{~m}$, to $6.4 \mathrm{moll}^{-1}$ at $80 \mathrm{~m}$ and then slowly until it went below our LOD $\left(1.4 \mu \mathrm{moll}^{-1}\right)$ at $230 \mathrm{~m}$ (Figure 1). Below $800 \mathrm{~m}$, oxygen returned to detectable concentrations and reached $100 \mathrm{\mu moll}^{-1}$ (30\% saturation) at $2500 \mathrm{~m}$ where it remained stable until the seabed $(>5000 \mathrm{~m})$. The baseline nitrite concentrations were 0.05 (LOD) to $0.2 \mu \mathrm{moll}^{-1}$ but within the OMZ, at 275-600 m, there was a large, secondary nitrite maximum of up to $1.8 \mu \mathrm{moll}^{-1}$ at $345 \mathrm{~m}$ and in the epipelagic waters, a smaller, primary maximum at around $50 \mathrm{~m}\left(\max 1.37 \mu \mathrm{mol} \mathrm{l}^{-1}\right)$ in most profiles (Figure 1). The true anoxic core of the OMZ was where oxygen was below the LOD and a clear secondary nitrite maximum was present $(230-600 \mathrm{~m})$.

Methane was supersaturated relative to the atmosphere throughout the water column and there was 


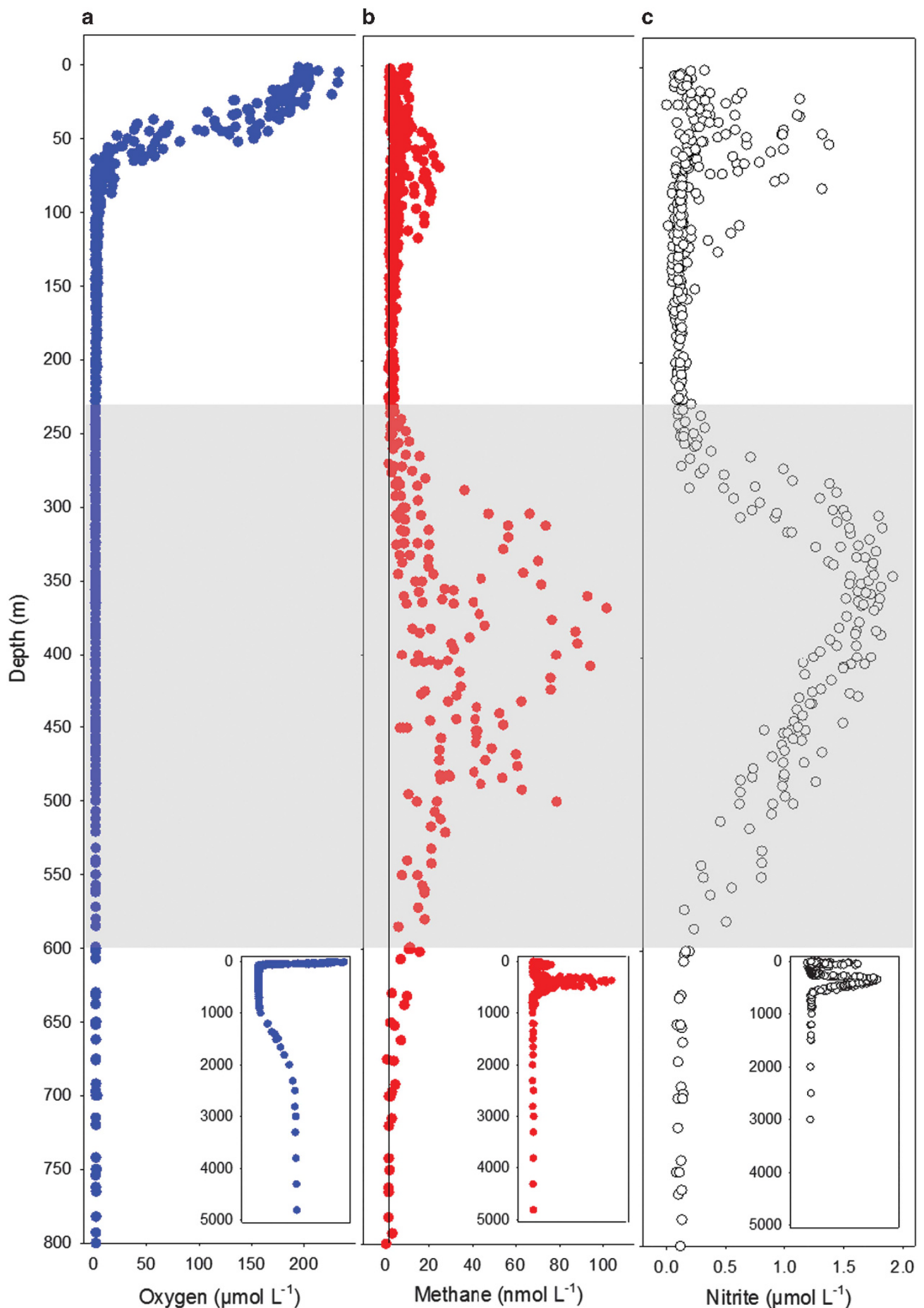

Figure 1 Water column profiles of (a) oxygen, (b) methane and (c) nitrite were constructed from conductivity-temperature-depth (CTD) deployments with the top $800 \mathrm{~m}$ shown in main panels and all data $(0-5000 \mathrm{~m})$ shown in inset plots. The shaded grey segment indicates

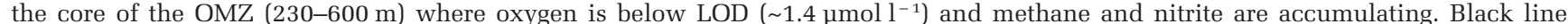
indicates atmospheric equilibration of methane at the depth-specific temperature and salinity. 
a clear peak around 250-600 m (Figure 1). The maximum concentration $\left(102 \mathrm{nmol}^{-1}\right)$ was measured at $368 \mathrm{~m}$ on the continental shelf where the seabed depth was $506 \mathrm{~m}$, although very close to the sediments $(<15 \mathrm{~cm}) 254 \mathrm{nmol} \mathrm{l}^{-1}$ was measured. Outside the core of the OMZ, the methane was consistently above atmospheric equilibration at $3-5 \mathrm{nmol} \mathrm{l}^{-1}$, except for a small epipelagic methane peak (Figure 1), which was only found in some of the profiles (maximum concentration $25 \mathrm{nmol} \mathrm{l}^{-1}$ at $65 \mathrm{~m}$ ).

\section{Methane flux, methanogenesis and the methanogen} community

In the intact, anoxic core incubations, methane flux averaged $262 \pm 65.5 \mathrm{nmol} \mathrm{m} \mathrm{m}^{-2} \mathrm{day}^{-1}$, peaking at $1007 \mathrm{nmol} \mathrm{m}^{-2}$ day $^{-1}$ at $550 \mathrm{~m}$ and with the slowest of $162 \mathrm{nmol} \mathrm{m}^{-2}$ day $^{-1}$ measured at $300 \mathrm{~m}$ (Figure 2a). Although all sediment cores were degassed to remove oxygen (that is, optimal conditions for methanogenesis), methane efflux was greater in sediments from locations where the OMZ intersected the shelf (indicated by shaded area on Figure 2a) compared with those with oxygenated $\left(2-4.6 \mu \mathrm{mol} \quad \mathrm{l}^{-1}\right)$ bottom-water $\left(X^{2}{ }_{(1)}=13.261\right.$, $P<0.0001)$. The efflux of methane from the sediments was positively correlated with the concentration of methane in the bottom-water $\left(X^{2}{ }_{(1)}=23.233, P<0.0001\right)$, which ranged from 6 to $254 \mathrm{nmol} \mathrm{l}^{-1}$ (Figure 2b). Further, there was a strong, non-linear inverse relationship between the concentration of methane and oxygen in the bottom-water (Figure 2b, inset, LOD 1.4 $\mu \mathrm{M} \mathrm{O}_{2}$ ).

Incubating anoxic sediment slurries from discrete depth intervals from two locations revealed that the bulk of the methanogenic potential was in the surface sediments (Figure 2c) and so all further experiments were focused on this layer (Table 1). Methanogenesis was also detected in the overlying water $(0-5 \mathrm{~cm}$ above sediment) and in sediments down to $25 \mathrm{~cm}$, but in the uppermost layer the rate was at least an order of magnitude higher than any other depth (Figure 2c). The greatest potential was measured in sediment from $750 \mathrm{~m}$ (88 $\mathrm{nmol} \mathrm{g}^{-1}$ day $^{-1}$, Table 1). Hydrogen sulphide was detected in two out of the six cores in which it was measured; at $550 \mathrm{~m}$ the concentration reached $59 \mu \mathrm{mol} \mathrm{l^{-1 }}$ at $25 \mathrm{~cm}$ (Figure 2c) and in a core from $350 \mathrm{~m}$ it reached $219 \mu \mathrm{mol} \mathrm{l^{-1 }}$ at $23 \mathrm{~cm}$. The porewater profiles (Supplementary Figure S3) revealed that in the top $2 \mathrm{~cm}$ of sediment, where methane production was most active, sulphate
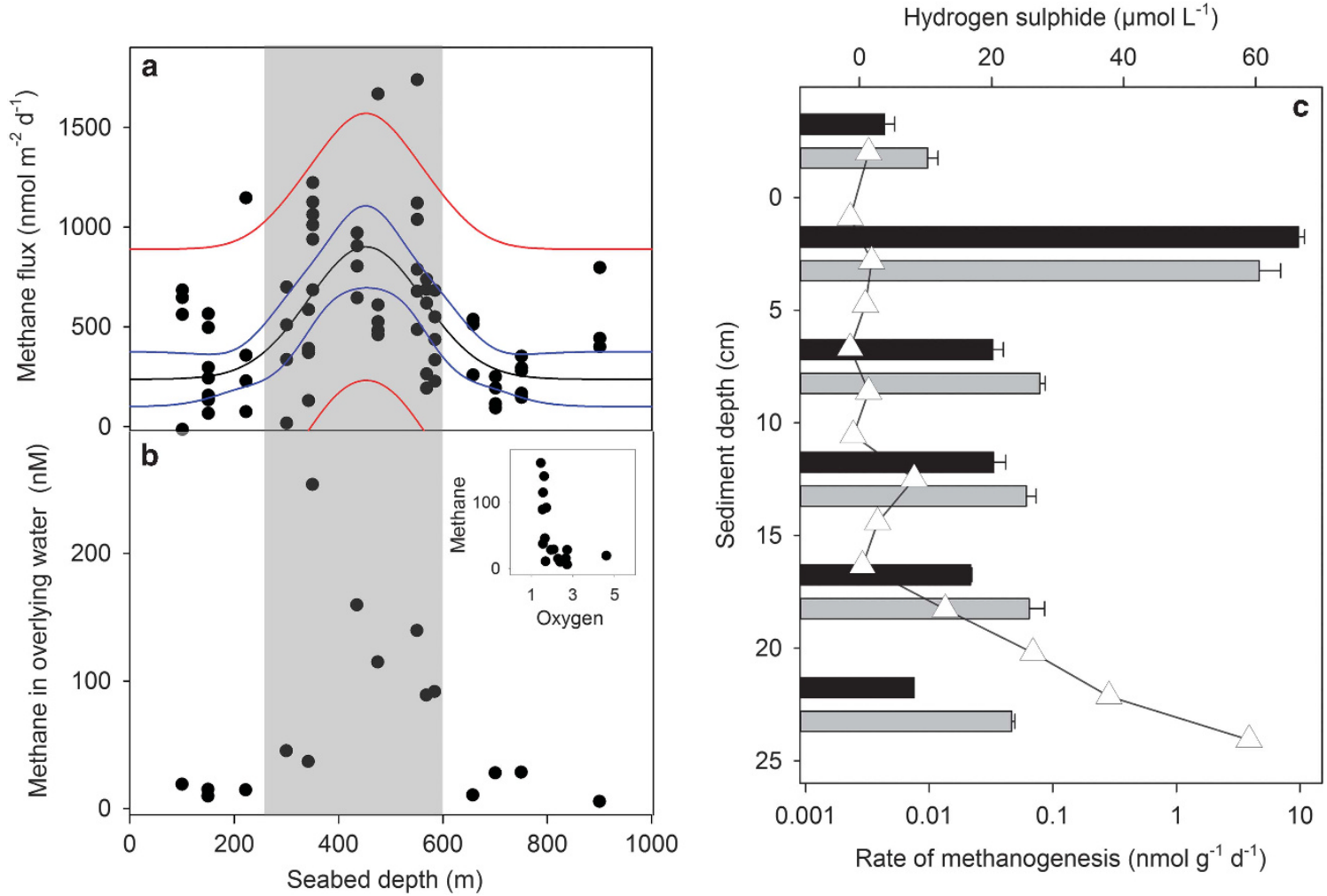

Figure 2 Spatial variation in (a) methane flux from sediment mini-cores and (b) methane concentration in the bottom, water measured above the cores ( $<15 \mathrm{~cm}$ from sediment surface), plotted against seabed depth. The shaded area indicates where the conductivity-temperaturedepth (CTD) profiles measured anoxic bottom water ( 10 m from seabed). The Gaussian peak, 4-paramter regression line (black), 95\% confidence (blue) and prediction (red) intervals are shown in a. Inset, oxygen concentration and methane concentration in the bottom water for the points shown in b. (c) Depth profiles of methanogenic potential (displayed on a logarithmic scale) measured in slurries at five discrete sediment layers from 0 to $25 \mathrm{~cm}$ in cores from $550 \mathrm{~m}$ (grey) and $650 \mathrm{~m}$ (black). As a result of this strong depth decay, all further experiments focused on the top $5 \mathrm{~cm}$ only. Hydrogen sulphide profile for a core from $550 \mathrm{~m}$ ( $650 \mathrm{~m}$ data unavailable) overlain in unfilled triangles. 


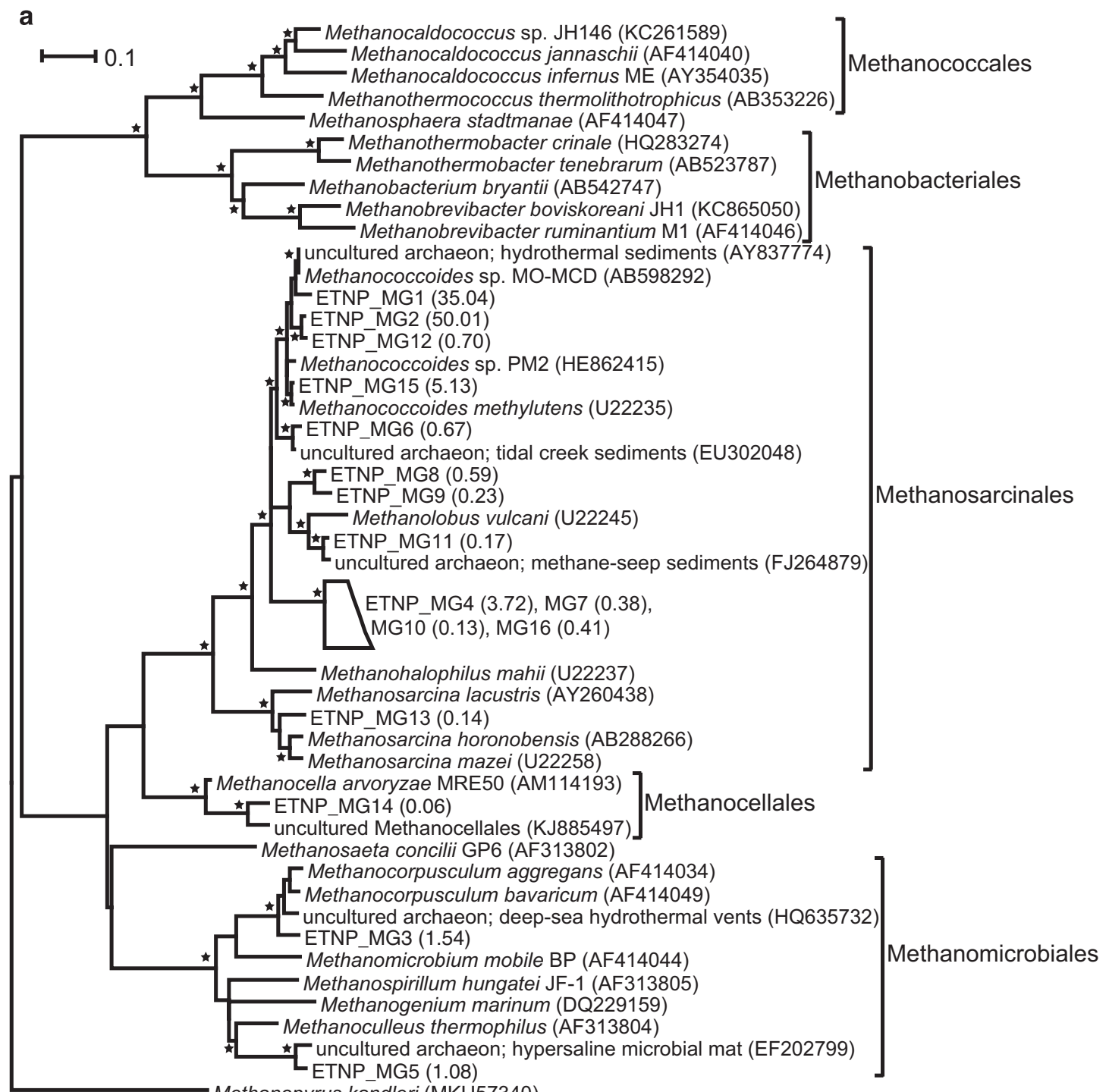

Methanopyrus kandleri (MKU57340)

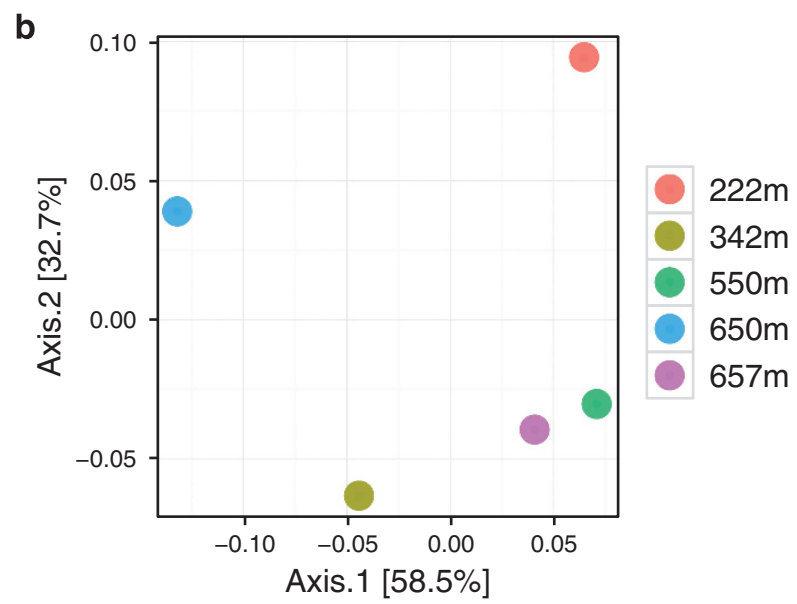

Figure 3 Methanogen community at five points across the seabed sediment. (a) Maximum likelihood tree of representative partial mcrA sequences (about $362 \mathrm{bp}$ ). Collapsed branches are indicated by a polygon. The mcrA gene of Methanopyrus kandleri (MKU57340) was used as the outgroup. Asterisks indicate local support values over $75 \%$. The number in parenthesis following the ETNP MG sequences indicates the \% relative abundance of each OTU over the total number of OTUs (see Supplementary Table S2 for details). The bar represents 0.1 average nucleotide substitutions per base. (b) Principal coordinate analysis (PCoA) plot of the methanogen community based on the mcrA sequences and a maximum likelihood tree, and, constructed with the weighted Unifrac metric. 
(23 $\left.\mathrm{mmol} \mathrm{l}^{-1}\right)$, nitrite $\left(2.8 \mu \mathrm{mol} \mathrm{l}^{-1}\right)$ and nitrate $\left(86 \mu \mathrm{mol} \mathrm{l}^{-1}\right)$ were similar to, or above, bottomwater concentrations.

A total of 126303 mcrA gene sequences from the top $2 \mathrm{~cm}$ were retrieved and clustered into 16 operational taxonomic units (OTUs), hereafter named as ETNP_MG. The majority of sequences (50\% of sequences represented by ETNP_MG2 and $35 \%$ represented by ETNP_MG1) were 96-97\% similar to Methanococcoides sp. (Supplementary Table S2). Most of the OTUs (13 out of 16) clustered within the order Methanosarcinales, whereas two OTUs (ETNP_MG3 and ETNP_MG5) clustered within the order Methanomicrobiales and one (ETNP_MG14) within the order Methanocellales (Figure 3a). The Methanococcoides-like species dominated all five seabed samples, which displayed a similar level of intra-sample diversity (assessed by Shannon and Simpson indices, Supplementary Table S2). Principal coordinate analysis indicates that most of the variation $(91.2 \%)$ in the methanogen community is explained by the first two principal coordinates (58.5\% of the variation explained by axis 1 and $32.7 \%$ by axis 2, Figure 3b). The most separated communities, by the first coordinate, are those from 650 to $222 \mathrm{~m}$, because of unique Methanomicrobiales (ETNP_MG5) and Methanocellales (ETNP_MG14) sequences at $650 \mathrm{~m}$ and Methanosarcinales at $222 \mathrm{~m}$. The community at $342 \mathrm{~m}$ is also somewhat separated from the others, as it is the only one with ETNP_MG3 Methanomicrobiales-like sequences.

\section{Methane oxidation and methanotrophs}

Methane oxidation was measured, through the accumulation of ${ }^{13} \mathrm{C}$-DIC, in short-term (10-15 days) time series incubations with water from the uppermost margins of the OMZ (Figure 4a and Supplementary Figure S2); ${ }^{13} \mathrm{C}$-DIC was produced at a rate of 3.0-5.9 $\mathrm{nmol} \mathrm{l}^{-1} \mathrm{day}^{-1}$, and, after 15 days, $26 \%$ of the ${ }^{13} \mathrm{C}^{-} \mathrm{CH}_{4}$ had been oxidised to ${ }^{13} \mathrm{C}$-DIC. In the epipelagic zone, we could not measure any methane oxidation at $47 \mathrm{~m}$ but we did at $65 \mathrm{~m}$ (Table 2). Our dose-response experiments indicate that the methanotrophs can oxidise methane at concentrations much higher than the ambient concentration (Figure 4b). Water from both the epipelagic $(65 \mathrm{~m})$ and mesopelagic waters $(200 \mathrm{~m}$, where oxygen was below detection) oxidised increasing amounts of ${ }^{13} \mathrm{C}^{-\mathrm{CH}_{4}}$ to ${ }^{13} \mathrm{DIC}$ with increasing initial methane spike (Figure 4b) and there was a good correlation between methane oxidised and ${ }^{13} \mathrm{C}$-DIC produced $\left(R^{2}=0.96\right)$. This relationship between ${ }^{13} \mathrm{C}-$ DIC produced and starting methane concentration was linear $\left(R^{2}{ }_{(200 \mathrm{~m})}=0.94\right.$ and $\left.R^{2}{ }_{(65 \mathrm{~m})}=0.54\right)$ for the range of concentrations tested $\left(85-760 \mathrm{nmol}^{-1}\right)$ and the slope $\left(b^{1}{ }_{(200 m)}=0.0055\right.$ and $\left.b^{1}{ }_{(65 m)}=0.0057\right)$ of the relationship was similar for the two different water samples (Figure 4b).

Long-term (5 months) incubations from eight different locations (47-228 m), yielded mixed results, with methane oxidation being undetectable in some vials (Table 2). The greatest amount of ${ }^{13} \mathrm{C}$ DIC produced was at $200 \mathrm{~m}$ where, following a $3.3 \mathrm{nmol}$ spike of ${ }^{13} \mathrm{C}^{-} \mathrm{CH}_{4}, 0.6 \mathrm{nmol}{ }^{13} \mathrm{C}$-DIC was measured in the water after 5 months. In the shorter incubations, water from the same location, produced a similar amount in only 10 days (Figure 4a), which indicates methane oxidation did not continue linearly during the 5 months. For comparison, if a total of $0.6 \mathrm{nmol}{ }^{13} \mathrm{C}$-DIC in the vial accumulated linearly, after 150 days, it would equate to $0.42 \mathrm{nmoll}^{-1}$ day $^{-1}$, which is 14 times slower than that measured in the short-term incubations.
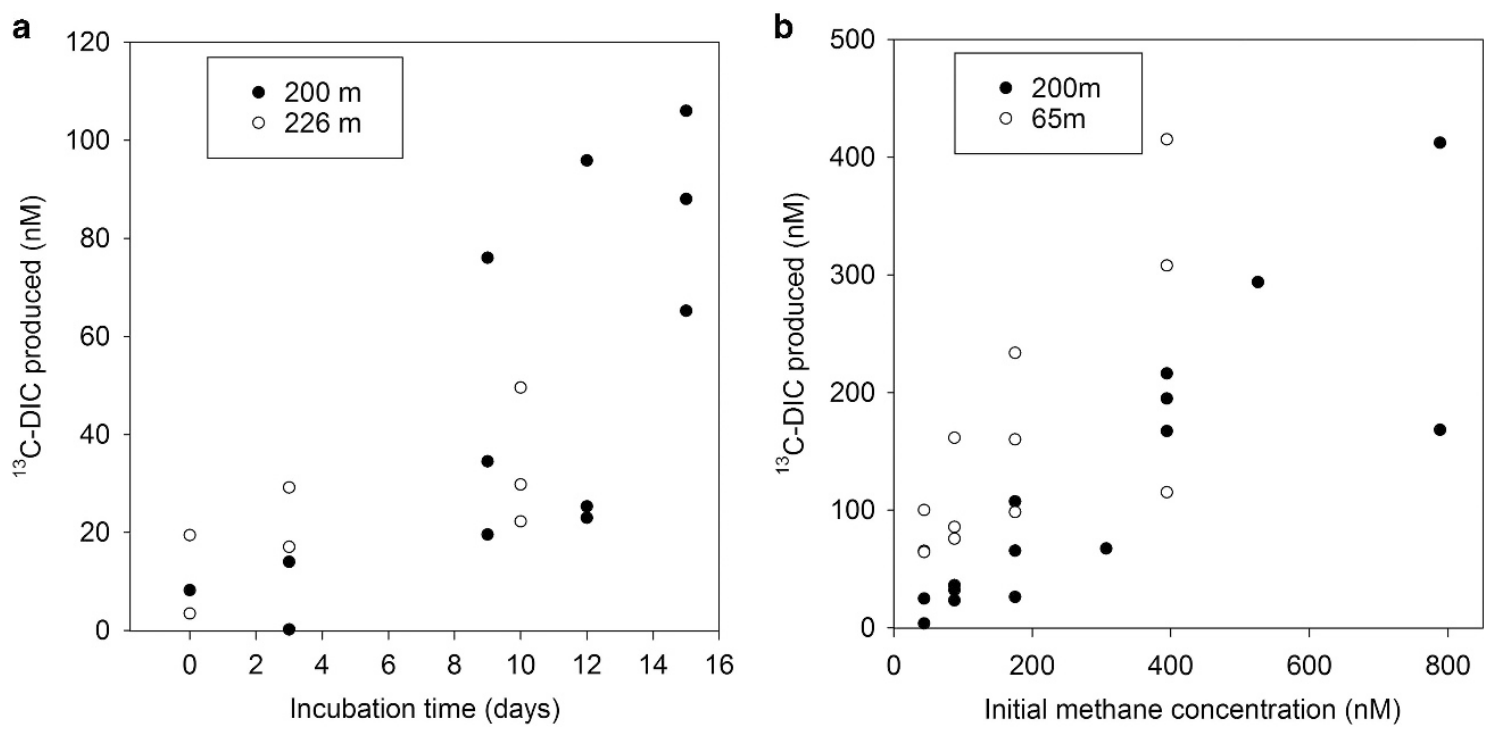

Figure 4 Methane oxidation measured as ${ }^{13} \mathrm{C}$-DIC accumulation, (a) over a 13-day time series with water from 200 to $226 \mathrm{~m}$, on the upper margin of the OMZ, where oxygen is close to LOD $\left(\sim 1.4 \mu \mathrm{mol} \mathrm{l}^{-1}\right)$ and methane is rising above background concentrations, and (b) over 5 months with varying initial concentrations of methane. 


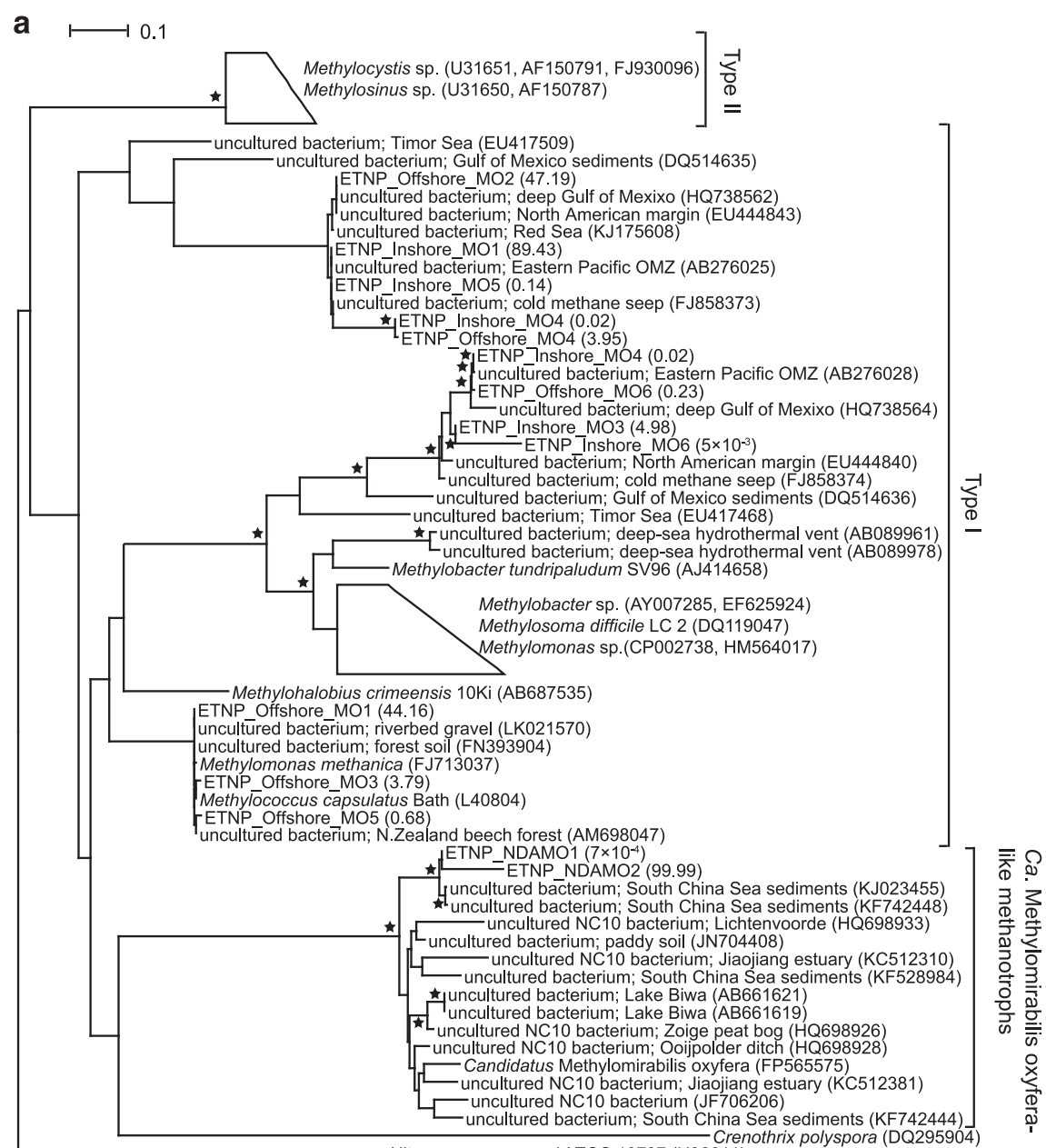

b

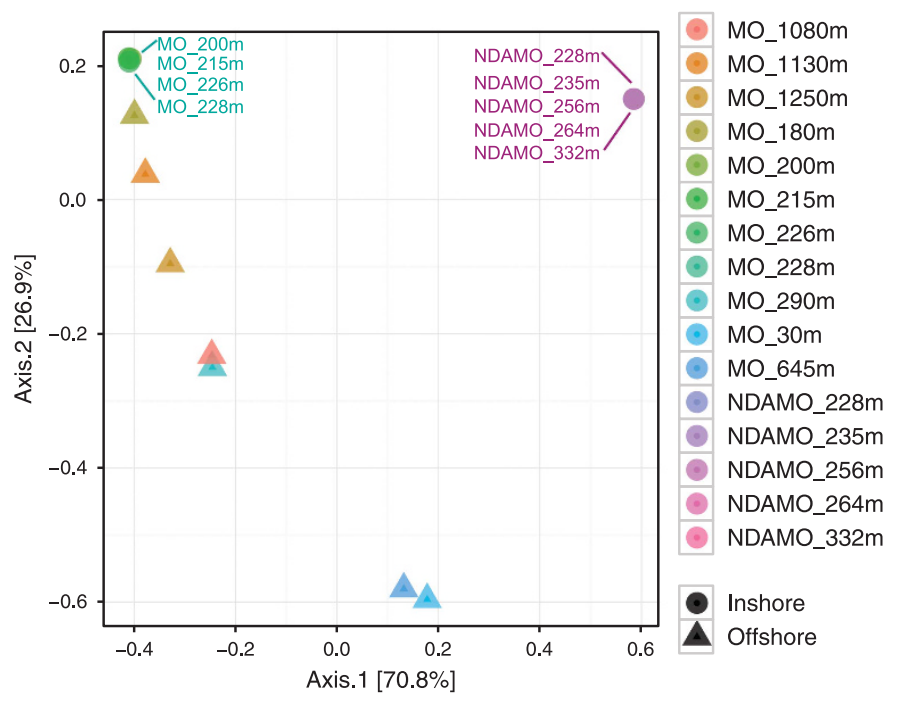

Figure 5 Aerobic and anaerobic methanotroph community of the water column. (a) Maximum likelihood tree of representative partial pmoA sequences (about $347 \mathrm{bp}$ ). Collapsed branches are indicated by a polygon. The amoA gene of Nitrosococcus oceani ATCC 19707 (U96611) was used as the outgroup. Asterisks indicate local support values over $75 \%$. The number in parenthesis following the ETNP Inshore MO, ETNP Offshore MO and ETNP NDAMO sequences indicates the \% relative abundance of each OTU over the total number of Inshore, Offshore and N-DAMO OTUs, respectively (see Supplementary Table S3 for details). The bar represents 0.1 average nucleotide substitutions per base. (b) Principal coordinate analysis (PCoA) plot of the methanotroph community based on the pmo $A$ sequences and a maximum likelihood tree, and, constructed with the weighted Unifrac metric. Circles indicate inshore samples and triangles indicate offshore samples. MO stands for aerobic methanotrophs and N-DAMO for anaerobic methanotrophs. MO_Inshore and N-DAMO communities are shown by overlapping green and purple circles, respectively. 
Water incubated with ${ }^{13} \mathrm{CH}_{4}$ and ${ }^{15} \mathrm{NO}_{2}^{-}$did produce both ${ }^{13} \mathrm{DIC}(0.9-15.4 \mathrm{nmol})$ and ${ }^{29+30} \mathrm{~N}_{2}$ (8.9-80.5 $\mathrm{nmol})$, and the relative proportions produced varied across depths with high rates of ${ }^{29+30} \mathrm{~N}_{2}$ production at 235 and $264 \mathrm{~m}$, indicative of nitrite reduction alongside methanotrophy (Table 2 and Supplementary Figure S2).

Methanotrophic bacteria were targeted in waters offshore (30-1250 m depth) and closer to the coast $(200$ and $228 \mathrm{~m})$. Analysed aerobic pmoA sequences in the offshore samples (6202 in total) were clustered into six OTUs, hereafter called ETNP_Offshore_MO, and in the inshore samples (363816 in total) were clustered into six OTUs, hereafter called ETNP_Inshore_MO. The sequences from both the offshore and inshore samples were highly similar (97-100\% BLAST similarity) to uncultured bacteria from marine environments (Supplementary Table S3, Figure 5a). The vast majority of the offshore sequences are represented by two OTUs, that is, ETNP_Offshore_MO1 $(44.16 \%$ of sequences) and ETNP_Offshore_MO2 (47.19\% of sequences). Similarly, ETNP_Inshore MO1 represents the majority $(89.43 \%)$ of the analysed inshore sequences. Phylogenetic analysis shows that all the OTUs cluster within known type I methanotrophs (Figure 5a). Among them, three OTUs of the offshore samples (ETNP_Offshore_MO1/MO3/MO5) sit within a sub-cluster of the family Methylococcaceae including Methylococcus and Methylomonas species.

The diversity (based on Shannon and Simpson indices) within all the analysed samples and particularly of the inshore ones is small, with the most diverse sample being that of $290 \mathrm{~m}$ offshore (Shannon $=1.19$, Simpson $=0.64$; Supplementary Table S3). The principal coordinate analysis plot also shows a very close proximity of all the inshore samples (that is, green circles on Figure 5b practically overlap), whereas there is some variance among the offshore samples, as indicated by their good separation along the second principal coordinate, that is, axis 2, explaining $26.9 \%$ of the observed variance (triangles in Figure 5b).

However, most of the principal coordinate analysis variance is explained by the first principal coordinate (axis 1, explaining 70.8\% of the variance), which is mainly driven by the divergence of the anaerobic methanotroph community (overlapping purple circles on Figure 5b) and, to a lesser extent, by the divergence of two offshore aerobic methanotroph samples (30 and $645 \mathrm{~m}$; blue triangles on Figure 5b). The diversity within the two OTUs of the anaerobic methanotrophs (ETNP_NDAMO1 and ETNP_NDAMO2) is minimal (see Shannon and Simpson indices, Supplementary Table S3). Indeed, phylogenetic analysis placed both of these OTUs into a separate and well-defined cluster, related to the Candidatus Methylomirabilis oxyfera anaerobic methanotroph (Figure 5a).

\section{Discussion}

Here we have shown that biological methanogenesis, in the surface layer of the seabed sediments, is a major source of methane to the ETNP OMZ. These are the first direct measurements of methane production in sediments from this region. The reactivity of these sulphate and nitrate-rich surface sediments highlights the potential importance of noncompetitive methanogenesis to the marine methane pool. Our oxygen profiles agree with previously published data for the ETNP OMZ (Burke et al., 1983; Sansone et al., 2001, 2004; Pack et al., 2015) and show oxygen to be $\leqslant 1.4 \mathrm{\mu mol} \mathrm{l}^{-1}$ between 200 and $800 \mathrm{~m}$. However, as a secondary nitrite maximum occurs when oxygen is below $0.05 \mu \mathrm{mol} \mathrm{l}^{-1}$ (Thamdrup et al., 2012), we used this profile to define the true core of the OMZ (230-600 m). In addition, we have presented evidence for microbial methane oxidation, which can be sustained under a wide range of oxygen $\left(<1.4-65 \mathrm{mmol} \mathrm{l}^{-1}\right)$ and methane (44$790 \mathrm{nmol} \mathrm{l}^{-1}$ ) concentrations, potentially controlling the release of methane emissions from the OMZ.

The highest potential for methanogenesis is in the top $2 \mathrm{~cm}$ of seabed, in the presence of ample sulphate, nitrate and nitrite (as alternative electron acceptors) and $>20 \mathrm{~cm}$ above the hydrogen sulphide peak (Figure 2c, Table 1). The co-occurrence of the greatest potential for methanogenesis and highest concentration of sulphate indicates that this is likely to be non-competitive methanogenesis and this is supported by the methanogen community findings. The majority of methanogens in all the analysed samples (97.31\% of total sequences) clustered within the family Methanosarcinaceae and the dominant OTUs were similar to Methanococcoides sp. deriving from sub-seafloor sediments (Imachi et al., 2011) or estuarine mudflats (Watkins et al., 2012). Methanococcoides sp. have often been isolated from marine sediments (for example, Singh et al., 2005; Lazar et al., 2011; Webster et al., 2015) and they are obligatory methylotrophic methanogens, that is, utilising only non-competitive substrates, such as methanol or methylamines (Garcia et al., 2000; Ferry, 2010).

Although we could not find other direct measurements of methanogenesis in the ETNP OMZ, there are data reported from other locations. Krüger et al. (2005) reported rates of methanogenesis in sediment surface slurries from eight different marine sites in the Atlantic, Pacific and Arctic Oceans and the North and Baltic Seas, and their results $\left(0.01-0.1 \mu \mathrm{molg}^{-1}\right.$ day $\left.^{-1}\right)$ agree well with our measurements using the same technique (0.001-0.09 $\mu \mathrm{mol} \mathrm{g}^{-1} \mathrm{day}^{-1}$, Table 1). They noted that the highest methanogenic potentials were measured in regions with high input of organic matter from the water column (Krüger et al., 2005). The only intact core experiment (Crill and Martens, 1983) to report marine methane flux was performed on coastal sediments from Cape Lookout Bight, and showed a similar range (0.18$1.56 \mu \mathrm{mol} \mathrm{m}^{-2}$ day $^{-1}$ ) to those found in our ETNP sediments $\left(0.16-1.01 \mu \mathrm{mol} \mathrm{m} \mathrm{m}^{-2}\right.$ day $\left.^{-1}\right)$. 
1396

The potential for methanogenesis was markedly reduced below the top $2 \mathrm{~cm}$ and we propose that this is linked to organic carbon supply raining down from above, which the surface methanogens can preferentially access. Continental shelves are known for high productivity and therefore, the delivery of carbon to the seafloor is high relative to less productive areas of the ocean (Ramaswamy et al., 2008; Fennel, 2010).

We propose that this benthic methanogenesis supplies the water column with methane, which persists far offshore. The location of the methane peak $(250-700 \mathrm{~m})$, agrees well with other ETNP studies but the magnitude in our study $\left(102 \mathrm{nmol} \mathrm{l}^{-1}\right.$ using the conductivity-temperature-depth and $254 \mathrm{nmol} \mathrm{l}^{-1}$ very close to the sediment surface using Mega-Cores) was considerably higher than previously reported (maximum 5-80 $\mathrm{nmoll}^{-1}$, Burke et al., 1983; Sansone et al., 2001, 2004 and Pack et al., 2015). Variation in maximum concentrations found across the ETNP is likely due to proximity to the source of methane, dilution and slow microbial oxidation. The flux was greatest when oxygen concentration in the bottom-water was below the LOD (Figure 2a) and a clear plume, originating in the continental shelf slope and extending offshore, can be seen in our profiles (Supplementary Figure S1), both of which support our theory. Even when there was a wedge of oxygenated water between the OMZ and the seafloor, methane was supersaturated in the OMZ and the maximum concentration of methane decreased with distance offshore. Indeed, methane was only found to be over $35 \mathrm{nmoll}^{-1}$ when the maximum water depth was between 350 and $650 \mathrm{~m}$, and in the deeper water (seabed $>750 \mathrm{~m}$ ) the methane did not exceed $25 \mathrm{nmoll}^{-1}$ even when oxygen and nitrite indicated true OMZ conditions. The close agreement between our potential methanogenesis rates and the flux data show that benthic methanogenesis could be responsible for all the methane measured in the bottomwater without the need to invoke additional methane sources, for example, seeps or dissociation of hydrates. Further, to the best of our knowledge, there are no reports of methane seeps in this OMZ.

The spatial alignment of the methane and nitrite peaks suggests that methane could be oxidised, in the presence of nitrite and the absence of measureable oxygen, that is, anaerobically. Our attempts to measure the potential for N-DAMO were inconclusive, and others (Padilla et al., 2016) using a similar dual-isotope incubation technique, recently tried and failed to fully quantify this process in the ETNP OMZ. However, in our experiments, water incubated with ${ }^{13} \mathrm{C}-\mathrm{CH}_{4}$ and ${ }^{15} \mathrm{~N}-\mathrm{NO}_{2}$ did produce ${ }^{13} \mathrm{C}$-DIC and ${ }^{29+30} \mathrm{~N}-\mathrm{N}_{2}$ but the stoichiometry (Table 2) was not indicative of pure N-DAMO $\left(3 \mathrm{CH}_{4}\right.$ and $8 \mathrm{NO}_{2}$ produce $3 \mathrm{CO}_{2}$ and $4 \mathrm{~N}_{2}$, Ettwig et al., 2010), nor were the rates of ${ }^{13} \mathrm{C}$-DIC production consistently stimulated by addition of nitrite. Nonetheless, sequences from N-DAMO-like bacteria were detected in all the targeted water depths. The sequences belonged to just two closely related phylotypes (ETNP_NDAMO_1 and ETNP_NDAMO_2; Figure 5, Supplementary Table S3) affiliated with uncultured anaerobic methanotrophs from South China Sea sediments (Chen et al., 2014, 2015). They clustered within the Candidatus Methylomirabilis oxyfera lineage, which is known to couple anaerobic methane oxidation to the reduction of nitrite (Ettwig et al., 2010; Haroon et al., 2013) and, although they are well described in lakes (Deutzmann and Schink, 2011; Kojima et al., 2012), paddy soils (Wang et al., 2012) and peatlands (Zhu et al., 2012), the ecological role of these phylotypes in marine environments has only recently been addressed (Chen et al., 2014; Li-Dong et al., 2014). More recently, Padilla et al. (2016) reported transcriptionally active Methylomirabilis-like NC10 phylotypes in all their ETNP sites, off the North Mexican coast, with the abundance of 16S rRNA transcripts peaking in the core of the OMZ, thereby confirming marine OMZs as a niche for such phylotypes. In agreement with recent findings in the South China Sea (Chen et al., 2015), we show that these marine phylotypes form a separate cluster from their equivalent freshwater phylotypes.

We were able to confirm the potential for aerobic methane oxidation in the OMZ of ETNP by measuring the conversion of ${ }^{13} \mathrm{C}_{-} \mathrm{CH}_{4}$ to ${ }^{13} \mathrm{C}$-DIC over relatively short timescales ( $<2$ weeks). We artificially raised the methane concentration, to ensure that ${ }^{13} \mathrm{C}_{-}-\mathrm{CH}_{4}$ (rather than ${ }^{12} \mathrm{C}-\mathrm{CH}_{4}$ ) constituted the overwhelming majority of the methane available for oxidation. However, we can use our dose-response experiment to approximate ambient rates of methane oxidation. For example, at $200 \mathrm{~m}$ the average methane concentration was $3.3 \mathrm{nmol}^{-1}$ so although we measured $4.5 \mathrm{nmoll}^{-1}$ day $^{-1}$ (incubated with $300 \mathrm{nmoll}^{-1} \mathrm{CH}_{4}$ ) in situ we would expect $0.0495 \mathrm{nmoll}^{-1}$ day $^{-1}$ with a turnover time of 67 days. Even in anoxic incubations (LOD for oxygen), ${ }^{13} \mathrm{C}$-DIC was produced following a spike of ${ }^{13} \mathrm{C}_{-}-\mathrm{CH}_{4}$ and so it is reasonable to predict that methanotrophs are oxidising methane right at the margin of the OMZ core and our measurements fall within the range recently reported for methane oxidation in the ETNP $\left(0.000034-4 \mathrm{nmol} \mathrm{l}^{-1}\right.$ day $^{-1}$, Pack et al., 2015).

Molecular analysis confirmed the presence of aerobic methane oxidisers at a wide range of depths (ranging from 30 to $1250 \mathrm{~m}$ ) in both offshore (ETNP Offsshore MO) and coastal (ETNP Inshore_MO) waters. The majority of methanotrophs from inshore waters (99.96\% of sequences) were phylogenetically related $(>97 \%$ similarity, Figure 5, Supplementary Table S3) to uncultured bacteria detected in the ETNP (Hayashi et al., 2007). The methanotrophs in the offshore samples were somewhat more diverse, with some similar to those in the 
inshore samples and others forming a separate subcluster with known Methylococcaceae species (for example, Methylomonas methanica and Methylococcus capsulatus str. Bath, Figure 5). This could be partly attributed to the difference in the range of depths from which the samples were obtained, that is, offshore samples were collected from depths between 30 and $1250 \mathrm{~m}$, whereas inshore samples were collected from a much narrower range of depths (200-228 m). Depth-related differences in the aerobic methanotroph community along vertical water horizons have been reported elsewhere (for example, Tavormina et al., 2010, 2013). Such differences may be related to the physical transport of waters, harbouring distinct microbial communities, which, along with environmental selection and spatial separation, has been shown to shape the distribution of marine microbes (Wilkins et al., 2013; Steinle et al., 2015). The diversity of methanotroph phylotypes in the water column is likely controlled by environmental factors rather than geographical proximity, and the same phylotypes may be adapted to a range of methane concentrations (Tavormina et al., 2008). Indeed, a later study of Cu-MMO phylotypes from the CostaRican OMZ showed that methane concentration did not predict the occurrence, abundance or distribution of any phylotypes; instead environmental factors such as depth, salinity, temperature and dissolved oxygen concentrations accounted for most of the observed phylotype variance (Tavormina et al., 2013). Aerobic methanotrophs in both offshore and inshore samples clustered within type I, whereas no sequences were affiliated to type II methanotrophs, which is in accordance with the findings in other marine environments (Schubert et al., 2006; Tavormina et al., 2008; Wasmund et al., 2009; Schmale et al., 2012). The lack of close affiliation of marine phylotypes with established methanotroph lineages has been reported previously and it has been linked to specialisation of these phylotypes in marine environments and to the rather small representation of marine methanotroph sequences in public databases (Tavormina et al., 2008; Wasmund et al., 2009).

Here we present clear evidence for microbial methanogenesis in the continental shelf sediments fuelling the ETNP OMZ methane plume, which is sustained several $100 \mathrm{~km}$ offshore, despite biological oxidation. Molecular analyses support the methanogenesis and methanotrophy potentials presented, however, more studies are needed to fully unravel the diversity of pelagic methanotrophs and to determine the precise electron acceptors for anaerobic methane oxidation.

\section{Conflict of Interest}

The authors declare no conflict of interest.

\section{Acknowledgements}

This work was funded by the Natural Environment Research Council (grant NE/E01559X/1). We thank Dr Ian Sanders for general technical assistance, John Green for support with the Dionex and Nele Thijs for DNA extraction of the ETNP_Offshore_MO samples. We appreciate the support of the Captain and crew of RRS Discovery (cruise D373) and RRS James Cook (cruise JC097).

\section{References}

Blumenberg M, Seifert R, Michaelis W. (2007). Aerobic methanotrophy in the oxic-anoxic transition zone of the Black Sea water column. Org Geochem 38: 84-91.

Boetius A, Wenzhofer F. (2013). Seafloor oxygen consumption fuelled by methane from cold seeps. Nat Geosci 6: 725-734.

Burke RA, Reid DF, Brooks JM, Lavoie DM. (1983). Upper water column methane geochemistry in the Eastern Tropical North Pacific. Limnol Oceanogr 28: 19-32.

Chen J, Jiang X-W, Gu J-D. (2015). Existence of novel phylotypes of nitrite-dependent anaerobic methaneoxidizing bacteria in surface and subsurface sediments of the South China Sea. Geomicrobiol J 32: 1-10.

Chen J, Zhou Z-C, Gu J-D. (2014). Occurrence and diversity of nitrite-dependent anaerobic methane oxidation bacteria in the sediments of the South China Sea revealed by amplification of both $16 \mathrm{~S}$ rRNA and pmoA genes. Appl Microbiol Biotechnol 98: 5685-5696.

Crill PM, Martens CS. (1983). Spatial and temporal fluctuation of methane production in anoxic coastal marine sediments. Limnol Oceanogr 28: 1117-1130.

D’Hondt S, Rutherford S, Spivack AJ. (2002). Metabolic activity of subsurface life in deep-sea sediments. Science 295: 2067-2070.

Deutzmann JS, Schink B. (2011). Anaerobic oxidation of methane in sediments of Lake Constance, an oligotrophic freshwater lake. Appl Environ Microbiol 77: 4429-4436.

Ettwig KF, Butler MK, Le Paslier D, Pelletier E, Mangenot S, Kuypers MMM et al. (2010). Nitrite-driven anaerobic methane oxidation by oxygenic bacteria. Nature 464: $543-548$.

Fennel K. (2010). The role of continental shelves in nitrogen and carbon cycling: Northwestern North Atlantic case study. Ocean Sci 6: 539-548.

Ferry JG. (2010). How to make a living by exhaling methane. Annu Rev Microbiol 64: 453-473.

Ferry JG, Lessner DJ. (2008). Methanogenesis in marine sediments. Ann N Y Acad Sci 1125: 147-157.

Garcia JL, Patel BK, Ollivier B. (2000). Taxonomic, phylogenetic, and ecological diversity of methanogenic Archaea. Anaerobe 6: 205-226.

Haroon MF, Hu S, Shi Y, Imelfort M, Keller J, Hugenholtz P et al. (2013). Anaerobic oxidation of methane coupled to nitrate reduction in a novel archaeal lineage. Nature 500: 567-570.

Hayashi T, Obata H, Gamo T, Sano Y, Naganuma T. (2007). Distribution and phylogenetic characteristics of the genes encoding enzymes relevant to methane oxidation in oxygen minimum zones of the Eastern Pacific Ocean. Res J Environ Sci 1: 275-284. 
Heintz MB, Mau S, Valentine DL. (2012). Physical control on methanotrophic potential in waters of the Santa Monica Basin, Southern California. Limnol Oceanogr 57: 420-432.

Helm KP, Bindoff NL, Church JA. (2011). Observed decreases in oxygen content of the global ocean. Geophys Res Lett 38: L23602.

Imachi H, Aoi K, Tasumi E, Saito Y, Yamanaka Y, Saito Y et al. (2011). Cultivation of methanogenic community from subseafloor sediments using a continuous-flow bioreactor. ISME J 5: 1913-1925.

Keeling RE, Körtzinger A, Gruber N. (2010). Ocean deoxygenation in a warming world. Ann Rev Mar Sci 2: 199-229.

Kessler ID, Valentine DL, Redmond MC, Du M, Chan EW, Mendes SD et al. (2011). A persistent oxygen anomaly reveals the fate of spilled methane in the deep Gulf of Mexico. Science 331: 312-315.

Kirschke S, Bousquet P, Ciais P, Saunois M, Canadell JG, Dlugokencky EJ et al. (2013). Three decades of global methane sources and sinks. Nat Geosci 6: 813-823.

Knittel K, Boetius A. (2009). Anaerobic oxidation of methane: progress with an unknown process. Annu Rev Microbiol 63: 311-334.

Kojima H, Tsutsumi M, Ishikawa K, Iwata T, Mußmann M, Fukui M. (2012). Distribution of putative denitrifying methane oxidizing bacteria in sediment of a freshwater lake, Lake Biwa. Syst Appl Microbiol 35: 233-238.

Krüger M, Treude T, Wolters H, Nauhaus K, Boetius A. (2005). Microbial methane turnover in different marine habitats. Palaeogeogr Palaeoclimatol Palaeoecol 227: 6-17.

Lashof DA, Ahuja DR. (1990). Relative contributions of greenhouse gas emissions to global warming. Nature 344: 529-531.

Lazar CS, Parkes RJ, Cragg BA, L'Haridon S, Toffin L. (2011). Methanogenic diversity and activity in hypersaline sediments of the centre of the Napoli mud volcano, Eastern Mediterranean Sea. Environ Microbiol 13: 2078-2091.

Li-Dong S, Qun Z, Shuai L, Ping D, Jiang-Ning Z, Dong-Qing C et al. (2014). Molecular evidence for nitrite-dependent anaerobic methane-oxidising bacteria in the Jiaojiang Estuary of the East Sea (China). Appl Microbiol Biotechnol 98: 5029-5038.

Martens CS, Berner RA. (1977). Interstitial water chemistry of anoxic Long Island Sound sediments. 1. Dissolved gases. Limnol Oceanogr 22: 10-25.

Mau S, Blees J, Helmke E, Niemann H, Damm E. (2013). Vertical distribution of methane oxidation and methanotrophic response to elevated methane concentrations in stratified waters of the Arctic fjord Storfjorden (Svalbard, Norway). Biogeosciences 10: 6267-6278.

Mitterer RM. (2010). Methanogenesis and sulfate reduction in marine sediments: a new model. Earth Planet Sci Lett 295: 358-366.

Naqvi SWA, Bange HW, Farías L, Monteiro PMS, Scranton MI, Zhang J. (2010). Marine hypoxia/anoxia as a source of $\mathrm{CH}_{4}$ and $\mathrm{N}_{2} \mathrm{O}$. Biogeosciences 7: 2159-2190.

Nicholls JC, Davies CA, Trimmer M. (2007). Highresolution profiles and nitrogen isotope tracing reveal a dominant source of nitrous oxide and multiple pathways of nitrogen gas formation in the central Arabian Sea. Limnol Oceanogr 52: 156-168.
Oremland RS, Marsh LM, Polcin S. (1982). Methane production and simultaneous sulphate reduction in anoxic, salt marsh sediments. Nature 296: 143-145.

Pack MA, Heintz MB, Reeburgh WS, Trumbore SE, Valentine DL, Xu X et al. (2015). Methane oxidation in the Eastern Tropical North Pacific Ocean water column. J Geophys Res Biogeosciences 120: 1078-1092.

Padilla C, Bristow LA, Sarode N, Garcia-Robledo E, Gómez Ramirez E, Benson CR et al. (2016). NC10 bacteria in marine oxygen minimum zones. ISME J 10: 2067-2071.

Paulmier A, Ruiz-Pino D. (2009). Oxygen minimum zones (OMZs) in the modern ocean. Prog Oceanogr 80: 113-128.

Ramaswamy V, Gaye B, Shirodkar PV, Rao PS, Chivas AR, Wheeler D et al. (2008). Distribution and sources of organic carbon, nitrogen and their isotopic signatures in sediments from the Ayeyarwady (Irrawaddy) continental shelf, northern Andaman Sea. Mar Chem 111: 137-150.

Reeburgh WS. (2007). Oceanic methane biogeochemistry. Chem Rev 107: 486-513.

Reeburgh WS, Ward BB, Whalen SC, Sandbeck KA, Kilpatrickt KA, Kerkhof LJ. (1991). Black Sea methane geochemistry. Deep Sea Res Part A Oceanogr Res Pap 38: S1189-S1210.

Sanders IA, Heppell CM, Cotton JA, Wharton G, Hildrew AG, Flowers EJ et al. (2007). Emission of methane from chalk streams has potential implications for agricultural practices. Freshw Biol 52: 1176-1186.

Sansone F, Graham A, Berelson W. (2004). Methane along the western Mexican margin. Limnol Oceanogr 49: $2242-2255$

Sansone FJ, Popp BN, Gasc A, Graham AW, Rust TM. (2001). Highly elevated methane in the Eastern Tropical North Pacific and associated isotopically enriched fluxes to the atmosphere. Geophys Res Lett 28: $4567-4570$.

Schmale O, Blumenberg M, Kießlich K, Jakobs G, Berndmeyer C, Labrenz $\mathrm{M}$ et al. (2012). Aerobic methanotrophy within the pelagic redox-zone of the Gotland Deep (central Baltic Sea). Biogeosciences 9: 4969-4977.

Schubert CJ, Coolen MJL, Neretin LN, Schippers A, Abbas B, Durisch-Kaiser E et al. (2006). Aerobic and anaerobic methanotrophs in the Black Sea water column. Environ Microbiol 8: 1844-1856.

Shakhova N, Semiletov I, Panteleev G. (2005). The distribution of methane on the Siberian Arctic shelves: Implications for the marine methane cycle. Geophys Res Lett 32: 1-4.

Singh N, Kendall M, Liu Y, Boone D. (2005). Isolation and characterization of methylotrophic methanogens from anoxic marine sediments in Skan Bay, Alaska: description of Methanococcoides alaskense sp nov., and emended description of Methanosarcina baltica. Int J Syst Evol Microbiol 55: 2531-2538.

Steinle L, Graves CA, Treude T, Ferré B, Biastoch A, Bussmann I et al. (2015). Water column methanotrophy controlled by a rapid oceanographic switch. Nat Geosci 8: 378-382.

Stramma L, Johnson GC, Sprintall J, Mohrholz V. (2008). Expanding oxygen-minimum zones in the tropical oceans. Science 320: 655-658.

Tavormina PL, Ussler W, Steele JA, Connon SA, Klotz MG, Orphan VJ. (2013). Abundance and distribution of diverse membrane-bound monooxygenase (Cu-MMO) genes within the Costa Rica oxygen minimum zone. Environ Microbiol Rep 5: 414-423. 
Tavormina PL, Ussler W, Joye SB, Harrison BK, Orphan VJ. (2010). Distributions of putative aerobic methanotrophs in diverse pelagic marine environments. ISME J 4: 700-710.

Tavormina PL, Ussler W, Orphan VJ. (2008). Planktonic and sediment-associated aerobic methanotrophs in two seep systems along the North American margin. Appl Environ Microbiol 74: 3985-3995.

Thamdrup B, Dalsgaard T, Revsbech NP. (2012). Widespread functional anoxia in the oxygen minimum zone of the Eastern South Pacific. Deep Sea Res Part I Oceanogr Res Pap 65: 36-45.

Valentine DL. (2011). Emerging topics in marine methane biogeochemistry. Ann Rev Mar Sci 3: 147-171.

Vázquez-Domínguez E, Vaqué D, Gasol JM. (2007). Ocean warming enhances respiration and carbon demand of coastal microbial plankton. Glob Chang Biol 13: 1327-1334.

Wang Y, Zhu G, Harhangi HR, Zhu B, Jetten MSM, Yin C et al. (2012). Co-occurrence and distribution of nitrite-dependent anaerobic ammonium and methane-oxidizing bacteria in a paddy soil. FEMS Microbiol Lett 336: 79-88.

Wasmund K, Kurtböke DI, Burns KA, Bourne DG. (2009). Microbial diversity in sediments associated with a shallow methane seep in the tropical Timor Sea of Australia reveals a novel aerobic methanotroph diversity. FEMS Microbiol Ecol 68: 142-151.

Watkins AJ, Roussel EG, Webster G, Parkes RJ, Sass H. (2012). Choline and N,N-dimethylethanolamine as direct substrates for methanogens. Appl Environ Microbiol 78: 8298-8303.

Webster G, O’Sullivan LA, Meng Y, Williams AS, Sass AM, Watkins AJ et al. (2015). Archaeal community diversity and abundance changes along a natural salinity gradient in estuarine sediments. FEMS Microbiol Ecol 91: 1-18.
Whiticar MJ. (2002). Diagenetic relationships of methanogenesis, nutrients, acoustic turbidity, pockmarks and freshwater seepages in Eckernförde Bay. Mar Geol 182: 29-53.

Wilkins D, van Sebille E, Rintoul SR, Lauro FM, Cavicchioli R. (2013). Advection shapes Southern Ocean microbial assemblages independent of distance and environment effects. Nat Commun 4: 2457.

Wright JJ, Konwar KM, Hallam SJ. (2012). Microbial ecology of expanding oxygen minimum zones. Nat Rev Microbiol 10: 381-394.

Zhang X, Hester KC, Ussler W, Walz PM, Peltzer ET, Brewer PG. (2011). In situ Raman-based measurements of high dissolved methane concentrations in hydrate-rich ocean sediments. Geophys Res Lett 38: L08605.

Zhu B, van Dijk G, Fritz C, Smolders AJP, Pol A, Jetten MSM et al. (2012). Anaerobic oxidization of methane in a minerotrophic peatland: enrichment of nitritedependent methane-oxidizing bacteria. Appl Environ Microbiol 78: 8657-8665.

(c) (1) This work is licensed under a Creative Commons Attribution 4.0 International License. The images or other third party material in this article are included in the article's Creative Commons license, unless indicated otherwise in the credit line; if the material is not included under the Creative Commons license, users will need to obtain permission from the license holder to reproduce the material. To view a copy of this license, visit http:// creativecommons.org/licenses/by/4.0/

Supplementary Information accompanies this paper on The ISME Journal website (http://www.nature.com/ismej) 